\title{
WORKER HEALTH IN REFUSE-DERIVED FUEL PLANTS, A FIVE-YEAR FOLLOWUP
}

\author{
Seán MAHAR \\ The University of Wolverhampton, School of Applied Sciences, Wolverhampton, United Kingdom
}

Received February 2002

\begin{abstract}
Personal and area air monitoring data for endotoxins, contaminants of concern in the solid waste industry, were analysed to determine if recommended levels were exceeded and if problematic trends existed in comparison with previous measurements. Current and historic lung function and symptom information from the workforce was analysed to determine if values were within predicted norms and to observe any trends that might indicate work related ill health. Average personal exposures to endotoxins were well within recommended levels and remain unchanged from previous sampling. Lung functions in the workforce are within predicted normal values. No trends indicating reductions in lung function based on length of employment were observed and average values are in normal ranges.
\end{abstract}

KEY WORDS: endotoxins, length of employment, pulmonary function, solid waste industry

The waste processing industry has received considerable occupational health attention in recent years, much of it focusing on bioaerosol exposures and lung function decrements (1-4). This paper represents the continuation of a study on workers at two plants processing municipal solid waste into refuse-derived fuel (RDF). Concerns regarding potential health impacts among both workers and management initiated the study in 1995. A health records study conducted in 1995 using historical data of the workers at the two plant showed the most common symptoms occurring among the workers were back problems and headaches, followed by skin rashes and colds, then flu, hay fever and ear problems (5). Lung function values of the workers were analysed for length of time employed related trends. No significant correlations with time were shown for $\mathrm{FEV}_{1}$ when the lung function values were plotted against year since initial testing for a subset of workers employed more than five years. A slight positive correlation with time was shown for FVC.

An on-site health study conducted in 1995 included a questionnaire that indicated significant elevations in diarrhoea at work, nasal irritation (without cold), and cough with phlegm (without cold) for RDF workers relative to a reference population (6). Skin rash in the previous year, more than one skin rash in the previous year and having redness and itching of the arms were also reported more often in RDF workers than in workers employed elsewhere. Cross-shift lung function testing in the workers was conducted for the workforce. Statistically significant decrements were observed for FVC and $\mathrm{FEV}_{1}$, although these were not especially significant from a physiological basis since mean values remained over $100 \%$ predicted and the mean decrement was $2 \%$ or less.

During the year 2000 environmental sampling was again conducted for endotoxins and lung function tests were again given to the workers.

\section{METHODOLOGY}

Environmental monitoring samples for airborne endotoxins were collected at the plants by contracted environmental professionals. The samples were 
taken on $0.45-\mu \mathrm{m}$ pore size endotoxin-free filters in closed-faced, 37-mm cassettes using calibrated personal sampling pumps. The filters were assayed for endotoxin content using the Limulus amebocyte lysate (LAL) kinetic chromogenic assay as previously described $(7,8)$. Endotoxin concentrations are expressed as $\mathrm{EU} / \mathrm{m} 3$. The data were analysed to determine if exposures exceeded recommended levels or were otherwise of a magnitude likely to cause problems in the workforce. Differences were sought between the plants, historical levels and values published for the industry. Workers rotate jobs as previously reported, so while task-related daily exposures may vary, cumulative exposures are primarily homogenous (8).

Pulmonary function testing was performed on seated subjects, without noseclips by company occupational health personnel following American Thoracic Society recommendations as previously described (6). Values are reported as percent of predicted, with predictor values taken from Crapo and co-workers (9). The data were analysed for trends that might indicate health problems in the workforce such as values below predicted norms, decrements over time or differences between the plants. The information collected was analysed with the SYSTAT ${ }^{\circledR}$ statistical analysis program (SPSS, Chicago, IL).

\section{RESULTS}

\section{Personal endotoxin exposures}

The personal exposures to endotoxins did not change since the sampling conducted five years ago as tested by $t$-test adjusted for unequal variances $(\mathrm{P}=0.969)$. The geometric mean (GM) in 1995 was $28.5 \mathrm{EU} / \mathrm{m}^{3}(\mathrm{~N}=105)$ with geometric standard deviation (GSD) 2.77, and the GM in 2000 was $28.1 \mathrm{EU} / \mathrm{m}^{3}(\mathrm{GSD}=6.65 ; \mathrm{N}=42)$. The $\mathrm{GM}$ of all 147 personal measures taken to date is $28.4 \mathrm{EU} / \mathrm{m}^{3}$, with a GSD of 3.75. Figure 1 shows a box plot of the log-transformed measurements.

The personal exposures to endotoxins did not differ between plants statistically in the year 2000 as measured by $t$-test adjusted for unequal variances $(P=0.476)$, although the geometric mean value of the Plant A measures was lower. The trend towards lower endotoxin values at Plant $A$ was also the case in 1995, and was then statistically significant (Mann-Whitney, $\mathrm{P}=0.029$ ), probably because of the larger number of samples. The analysis of variance was conducted to

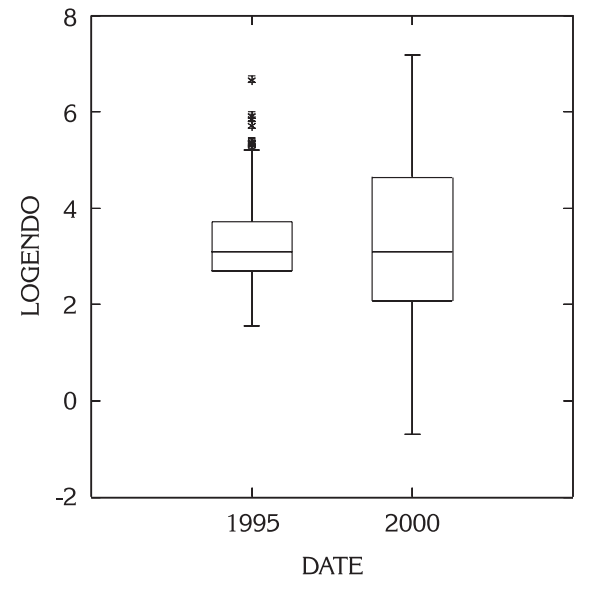

Figure 1 Box plot of (log-transformed) personal endotoxin exposures

test for differences in the plants and years, and only interplant differences were found to be significant $(P=0.030)$. Other comparisons were not found non-significant by the pairwise Tukey tests. Table 1 presents the personal exposures to endotoxins, by plant and year.

Table 1 Personal endotoxin exposures by plant, in $E U / \mathrm{m}^{3}$

\begin{tabular}{ccccc}
\hline Plant & Year & N & $\begin{array}{c}\text { Geometric } \\
\text { mean }\end{array}$ & $\begin{array}{c}\text { Geometric } \\
\text { standard } \\
\text { deviation }\end{array}$ \\
\hline \multirow{2}{*}{ A } & 2000 & 20 & 22.5 & 8.3 \\
& 1995 & 51 & 20.7 & 2.0 \\
\hline \multirow{2}{*}{ B } & 2000 & 22 & 34.5 & 5.5 \\
& 1995 & 54 & 38.4 & 3.2 \\
\hline
\end{tabular}

Mean exposures were well below personal endotoxin exposure guidelines of $100 \mathrm{EU} / \mathrm{m}^{3}$ for the prevention of airways inflammation and $1,000 \mathrm{EU} / \mathrm{m}^{3}$ for prevention of systemic effects as suggested by Rylander (10). There were individual exposures above the no-effect level guidelines; of the 147 personal exposure measurements taken to date $26(17.7 \%)$ were over $100 \mathrm{EU} / \mathrm{m}^{3}$, with one exposure above 1,000 $\mathrm{EU} / \mathrm{m}^{3}$ at $1,306 \mathrm{EU} / \mathrm{m}^{3}$.

\section{Area endotoxin measurements}

The area measurements of endotoxin concentration did not change in magnitude since the testing conducted five years ago as measured by $t$-test $(P=0.927)$. The geometric mean value of all 32 area measures taken to date is $30.1 \mathrm{EU} / \mathrm{m}^{3}$, with a geomet ric standard deviation of 5.40. Figure 2 presents box plots of the log-transformed measurements. 


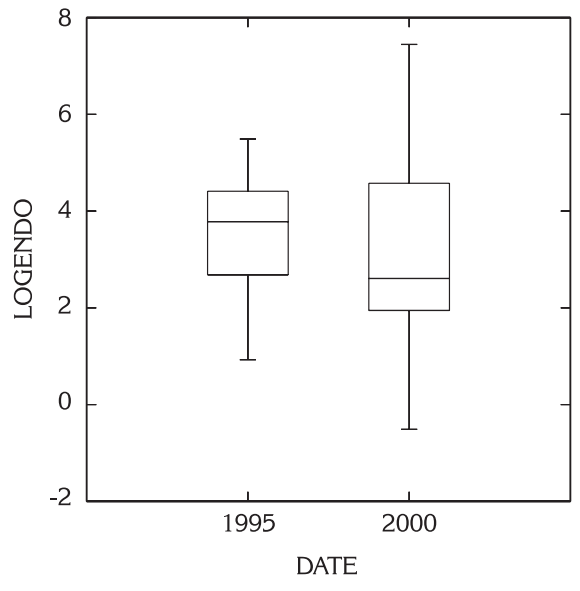

Figure 2 Box plot of (log-transformed) area endotoxin exposures

The geometric mean value of the Plant A area endotoxin measurements was lower than that of Plant $B$ although not statistically so, chiefly from the low number of samples. Table 2 presents the personal exposures to endotoxins, by plant and year.

Table 2 Area endotoxin exposures by plant, in $E U / \mathrm{m}^{3}$

\begin{tabular}{ccccc}
\hline Plant & Year & N & $\begin{array}{c}\text { Geometric } \\
\text { mean }\end{array}$ & $\begin{array}{c}\text { Geometric } \\
\text { standard } \\
\text { deviation }\end{array}$ \\
\hline \multirow{2}{*}{ A } & 2000 & 9 & 24.0 & 5.1 \\
& 1995 & 8 & 25.1 & 3.4 \\
\hline \multirow{2}{*}{ B } & 2000 & 9 & 27.5 & 11.3 \\
& 1995 & 6 & 60.6 & 2.9 \\
\hline
\end{tabular}

\section{Pulmonary function data}

The demographic breakdown of the 87 workers that had been employed longer than a year is shown in Table 3. Table 4 shows the results of the most recent round of lung function tests, by plant. No significant differences were found between the two plants for mean measures of percent predicted for any lung

Table 3 Study population demographics

\begin{tabular}{cccccc}
\hline Plant & N & $\begin{array}{c}\text { Mean age/years } \\
\text { (SD) }\end{array}$ & $\begin{array}{c}\text { Mean length of } \\
\text { employment/years (SD) }\end{array}$ & $\begin{array}{c}\text { Smokers } \\
\text { N (\%) }\end{array}$ & $\begin{array}{c}\text { Non-smokers* } \\
\text { N (\%) }\end{array}$ \\
\hline A & $\begin{array}{c}50 \\
(42 \text { men, 8 women) }\end{array}$ & $41.4(8.0)$ & $11.0(5.9)$ & $17(34)$ & $33(66)$ \\
\hline B & $\begin{array}{c}37 \\
(34 \text { men, 3 women })\end{array}$ & $39.9(8.1)$ & $7.7(5.4)$ & $16(43)$ & $21(57)$ \\
\hline
\end{tabular}

function parameter measured as determined by $t$-test [FVC $(\mathrm{P}=0.33), \mathrm{FEV}_{1}(\mathrm{P}=0.76)$ ]. Symptoms were not reported for the Plant $B$ workforce, but the Plant A workforce had 10 workers (20\%) that reported symptoms indicative of respiratory problems (3 with cough and wheezing, 3 with bronchitis, and 4 with pneumonia). Unfortunately, no control group was available to serve as an external comparison for either symptoms or lung functions. As there were no inter-plant differences observed, the workers were treated as a cohort to determine if there were any significant ventilatory function changes related to the length of employment.

Table 4 Ventilatory volumes (in \% of predicted) according to smoking habit (expressed as mean $\pm S D$ )

\begin{tabular}{ccccc}
\hline Plant & & Smokers & $\begin{array}{c}\text { Non- } \\
\text { smokers }\end{array}$ & All workers \\
\hline & & $\mathrm{N}=17$ & $\mathrm{~N}=33$ & $\mathrm{~N}=50$ \\
$\mathrm{~A}$ & $\mathrm{FVC}$ & $99.6(9.84)$ & $100.4(11.0)$ & $101.1(10.5)$ \\
& $\mathrm{FEV}_{1}$ & $97.2(12.0)$ & $101.2(12.9)$ & $99.8(12.6)$ \\
\hline & & $\mathrm{N}=16$ & $\mathrm{~N}=\mathbf{2 1}$ & $\mathrm{N}=37$ \\
$\mathrm{~B}$ & $\mathrm{FVC}$ & $101.8(18.1)$ & $103.4(10.8)$ & $102.7(14.2)$ \\
& $\mathrm{FEV}_{1}$ & $98.4(17.4)$ & $102.4(10.6)$ & $100.7(13.9)$ \\
\hline
\end{tabular}

Note: differences between the plants are not statistically significant

Comparisons were made by paired $t$-test between initial and most recent lung function tests for each of the lung function parameters measured, none of which were significant. Change in lung function was regressed on the time between the initial and the current test for all three parameters measured, all of which yielded positive yet not significant slopes. The mean time between the initial and current test was 8.9 years $(\mathrm{SD}=4.6)$; the results are presented in Table 5.

\section{Ventilatory function by length of employment}

\footnotetext{
*Never smoked and former smokers
} 
Table 5 Changes in ventilatory function (in \% of predicted) according to smoking habit

\begin{tabular}{cccc}
\hline & $\begin{array}{c}\text { Smokers } \\
\mathrm{N}=33\end{array}$ & $\begin{array}{c}\text { Non-smokers } \\
\mathrm{N}=54\end{array}$ & $\begin{array}{c}\text { All workers } \\
\mathrm{N}=87\end{array}$ \\
& Mean (SD) & Mean (SD) & Mean (SD) \\
\hline$\Delta \mathrm{FVC}$ & $-1.12(9.5)$ & $-0.53(13.2)$ & $-0.76(11.9)$ \\
$\Delta \mathrm{FEV}_{1}$ & $-2.26(12.1)$ & $-0.73(12.7)$ & $-1.31(12.5)$ \\
\hline
\end{tabular}

Note: differences in the groups based on initial and current measures are not statistically significant

The lung function data were then coded to group workers by length of employment to determine if length of employment has an impact on lung function. The groupings were 5 years or more vs. less than, 10 years or more vs. less than, and 15 years or more vs. less than. The length of employment groupings were compared by $t$-tests to see if there were differences in the current lung function measurements based on the length of employment and none were found. The values remain close to $100 \%$ of predicted as shown for the 10-year comparisons, as shown in Table 6. A similar comparison was made for the difference in lung function between initial and current measurements to determine if there was a difference in the change over time between the various length of employment cohorts. Again there were no physiologically significant differences in any of the comparisons, although a statistically significant difference $(P=0.025)$ occurred in smokers employed more than 15 years having an increase in $\mathrm{FEV}_{1}$ of $10.2 \%$ of predicted over time while those employed less had a decrease of $3.93 \%$ of predicted.

Table 6 Ventilatory volumes (in \% of predicted) according to the length of employment and smoking habit (expressed as mean $\pm S D$ )

\begin{tabular}{rcccc}
\hline $\begin{array}{c}\text { Emplo- } \\
\text { yed }\end{array}$ & Smokers & $\begin{array}{c}\text { Non- } \\
\text { smokers }\end{array}$ & All workers \\
\hline \multirow{2}{*}{$\begin{array}{c}\text { years } \\
\text { y }\end{array}$} & $\mathrm{FVC}$ & $101.8(9.84)$ & $104.8(11.2)$ & $103.5(14.7)$ \\
& $\mathrm{FEV}_{1}$ & $97.5(17.1)$ & $103.0(12.1)$ & $100.7(14.4)$ \\
\hline \multirow{3}{*}{$\mathbf{1 0}$} & & $\mathrm{N}=18$ & $\mathrm{~N}=33$ & $\mathrm{~N}=51$ \\
years & $\mathrm{FVC}$ & $99.8(9.28)$ & $99.4(10.3)$ & $99.5(9.89)$ \\
& $\mathrm{FEV}_{1}$ & $98.0(12.7)$ & $100.8(12.0)$ & $99.8(12.2)$ \\
\hline
\end{tabular}

Note: differences between all workers less/more than 10 years employed are not statistically significant

\section{CONCLUSIONS/RECOMMENDATIONS}

Both personal and area samples for endotoxins were within expected levels for the industry and remain unchanged from previous sampling. Mean personal exposures to endotoxins were below recommended no effect guidelines. The magnitude of the personal exposures to endotoxins were comparable to those in a study of a resource recovery plant in the Netherlands by Van Tongeren and co-workers who reported a 36.3 $\mathrm{EU} / \mathrm{m}^{3} \mathrm{GM}$ personal exposure level $(\mathrm{GSD}=2.6 ; \mathrm{N}=9$ ) (11). Some individual endotoxin exposures related to dusty work, such as the use of compressed air for cleaning surfaces, were above no effect guidelines. Respiratory protection should be used for these tasks and environmental monitoring continued, perhaps on an annual basis.

Endotoxin concentrations were found to be significantly correlated with inhalable dust concentrations $(r=0.67, P<0.01)$ and concentrations of total bioaerosols by fluorescent microscopy $(\mathrm{r}=0.27$, $\mathrm{P}<0.05$ ) in previous sampling, so it is likely that these exposures remain at the levels of $0.50 \mathrm{mg} / \mathrm{m}^{3}$ and $6.8 \times 10^{5}$ organisms $/ \mathrm{m}^{3}$ determined previously (8).

Pulmonary function values in the workforce are within predicted values and show no decrements over time for the workforce as a whole. Separating the workforce into cohorts based on the length of employment indicated no significant reductions in lung function for workers. Two statistically significant differences occurred, but neither was significant from a physiological basis or of a direction to indicate concern. Personnel records should be checked to determine if workers leave employment for reasons that might indicate work-related ill health. Some workers reported respiratory-related symptoms that may be related to work, although the numbers were low and there is no basis for comparison. A health questionnaire administered to the workforce (and a control population, which was not included in this study) might be useful to determine if there are indeed any problems.

It appears that long-term exposure to endotoxins in the range of $30 \mathrm{EU} / \mathrm{m}^{3}$ has no adverse effects on lung function in this cohort of workers. Although the workforce appears stable with minimal turnover, it would be advisable to look into the number of workers ceasing employment and their reasons to guard against the chance of a "healthy worker effect". 


\section{REFERENCES:}

1. Nersting L., Mamros P, Sigsgaard T, Petersen C. Biological health risk associated with resource recovery, sorting of recycle waste and composting. Grana 1991;30:454-7.

2. Collins C, Kennedy D. The microbiological hazards of municipal and clinical wastes. J Appl Bacteriol 1992;73:1-6.

3. Sigsgaard T, Abel A, Donbæk L, Malmros P. Lung function changes among recycling workers exposed to organic dust. Am J Ind Med 1994;25:69-72.

4. Poulsen OM, Breum N, Ebbehøj N, Hansen ÅM, Ivens UI, van Lelieveld D et al. Sorting and recycling of domestic waste. Review of occupational health problems and their possible causes. Sci Total Env 1995;168:33-56.

5. Mahar S, Reynolds S, Sprince N. Symptom prevalence, spirometry and lab values among refuse derived fuel workers. Arh Hig Rada Toksikol 1997;48:219-28.
6. Mahar S, Thorne PS. Worker health in two refusederived fuel plants. Arh Hig Rada Toksikol 1999;50: 249-61.

7. Mahar SM. Airborne particulates in refuse-derived fuel plants. Waste Manag Res 1999;17:343-346.

8. Mahar SM, Reynolds S, Thorne PS. Worker exposures to particulates, endotoxins, and bioaerosols in two refuse derived fuel plants. Am Ind Hyg Assoc $\mathrm{J}$ 1999;60:679-83.

9. Crapo RO, Morris AH, Gardner RM. Reference spirometric values using techniques and equipment that meet ATS recommendations. Am Rev Resp Dis 1981;123:659-64.

10. Rylander R. Evaluation of the risks of endotoxin exposures. Int J Occup Environ Health 1997;3 (Suppl): 32-6.

11. Van Tongeren M, Van Amelsvoort L, Heederik D. Exposure to organic dusts, endotoxins, and microorganisms in the municipal waste industry. Int J Occup Environ Health 1997;3:30-6. 


\section{Sažetak}

\section{PETOGODIŠNJE PRAĆENJE ZDRAVSTVENOGA STANJA RADNIKA NA PRERADI OTPADA U GORIVO}

Analizirani su rezultati praćenja razina endotoksina u zraku, značajnog onečišćivača u preradi otpada, te njegova učinka na zdravstveno stanje radnika na preradi otpada u gorivo. Cilj analize bio je utvrditi kreću li se razine endotoksina u okviru preporučenih, odnosno postoje li zabrinjavajući trendovi u odnosu na ranija mjerenja. Također su analizirana ranija i sadašnja mjerenja plućne funkcije, podaci o simptomima u radnika kako bi se vidjelo jesu li te vrijednosti unutar predviđenih te postoje li trendovi koji bi mogli upozoriti na pogoršanje njihova zdravstvenog stanja povezanog s radom.

Prosječna pojedinačna izloženost endotoksinima bila je u okviru preporučenih razina te se nije mijenjala u odnosu na ranija mjerenja. Plućne funkcije u radnika bile su unutar predviđenih normalnih vrijednosti. Nisu pronađeni nikakvi pokazatelji smanjenja plućne funkcije s obzirom na duljinu zaposlenja, a prosječne vrijednosti kretale su se u normalnim okvirima.

KLJUČNE RIJEČI: duljina zaposlenja, endotoksini, izloženost, kruti otpad, plućne funkcije

\section{REQUESTS FOR REPRINTS:}

Seán Mahar, Ph. D.

The University of Wolverhampton,

School of Applied Sciences,

62-68 Lichfield Street, WV1 1DJ Wolverhampton

United Kingdom

E-mail:S.Mahar@wlv.ac.uk 